Article

\title{
How Smog Awareness Influences Public Acceptance of Congestion Charge Policies
}

\author{
Lingyi Zhou and Yixin Dai * \\ School of Public Policy and Management, Tsinghua University, Beijing 100084, China; \\ ly-zhou14@mails.tsinghua.edu.cn \\ * Correspondence: yixindai@tsinghua.edu.cn
}

Received: 22 June 2017; Accepted: 30 August 2017; Published: 12 September 2017

\begin{abstract}
Although various studies have investigated public acceptance of congestion charge policies, most of them have focused on behavioral and policy-related factors, and did not consider the moderating influence that individual concern about smog and perceived smog risk may have on public acceptance. This paper takes the congestion charge policy in China, targeted at smog and traffic control, and checks how smog awareness-including smog concerns and perceived smog risks, besides behavioral and policy-related factors-might influence public acceptance of the policy. In this paper, we found both a direct and moderating causal relationship between smog awareness and public acceptance. Based on a sample of 574 valid questionnaires in Beijing and Shanghai in 2016, an ordered logistic regression modeling approach was used to delineate the causality between smog awareness and public acceptance. We found that both smog concerns, such as perceived smog risk, and willingness to pay (WTP) were both directly and indirectly positively correlated with public acceptance. These findings imply that policymakers should increase policy fairness with environmental-oriented policy design and should express potential policy effectiveness of the smog controlling policy to citizens to increase their acceptance level.
\end{abstract}

Keywords: sustainable development; smog concerns; perceived smog risks; public acceptance; congestion charge

\section{Introduction}

One of the biggest challenges facing environmental sustainability improvements is balancing greenhouse gas (GHG) emissions with the increasing needs of economic development and social improvement. As a rapidly developing country, China has an increasing number of vehicles that not only cause severe traffic jams but also severely pollute the air, including with fine particulate matter $\left(\mathrm{PM}_{2.5}\right)$, especially in large cities. Exposure to fine particulate matter $\left(\mathrm{PM}_{2.5}\right)$ can aggravate chronic respiratory and cardiovascular diseases, alter host defenses, damage lung tissue, and even lead to premature death and cancer [1]. Studies have indicated that road transport is one of the main sources of $\mathrm{PM}_{2.5}$ that accounts for approximately $25-30 \%$ of the emissions in major Chinese cities, such as Beijing [2], Shanghai [3], Guangzhou [4], Hangzhou [5], and Nanjing [6]. Controlling transportation emissions has become essential for Chinese cities to reach their sustainable development goals.

In many countries, congestion charges, which are fees charged to those who travel in certain areas with private vehicles [7], are viewed as a powerful tool to alleviate traffic-sourced GHG emissions, and have already been implemented in Singapore in 1975, London in 2003, Stockholm in 2006, and Milan in 2012. Congestion charge implementation has encountered public opposition in many cities, including Edinburgh and New York [8]. The Chinese government has tried to design a feasible congestion charge policy in pilot cities such as Beijing, Shanghai, Shenzhen, Hangzhou, and Nanjing; however, strong public opposition occurred before the policy was drafted. In an online opinion poll 
in Beijing in 2016, $61.4 \%$ of respondents disagreed with the implementation of a congestion charge policy [9].

As an authoritarian state, China's policy process is top-down, and the general public does not have a direct channel to express their opinion or attempt to influence policy [10]. With the development of civil society and the Internet and Communication Technology (ICT) sector, the general public has started to be more rights consciousness, meaning better interaction with the policy process, and having a better ability express their opinions in China [11]. In recent years, expressions of opposition are hardly new; many nuclear energy projects and paraxylene (PX) projects have been suspended or cancelled as a result of harsh public criticism, which has sometimes led to social instability [12,13]. As for smog control policies, noncompliance has occurred in some cities. Some people drive on plate restricted days, while others purchase multiples cars to break the driving restriction rules. Some even cover their plates or borrow plates from others [14]. Ignoring public opposition during smog control policy design may cause barriers for its implementation.

Existing literature shows that diverging perspectives toward sustainable issues, their causes, and solutions may lead to public opposition to policies that pursue sustainability goals. For example, some people may see traffic policies, such as congestion charge policies or traffic restriction policies, as being overall beneficial policies to society because they could drastically increase transportation efficiency and reduce emissions. Others may see these policies as restricting mobility, especially to low-income individuals, or those who live far away from public service facilities [15-19]. Although existing literature has discussed congestion charge policies regarding its traffic control goals, two questions still remain. Firstly, congestion charge policies for metropolitan cities and their ability to meet the sustainable goal of emission reduction has not been considered in the context of public opposition. The London government, for example, designed its congestion charge policy mainly for traffic control purposes, yet, it still calculated the emission reduction efforts during the policy adjustment process to determine if the fee should be adjusted for cars with ultra-low emission vehicles. The Beijing municipal government added GHG emission control as a major policy goal when the congestion charge policy draft was designed. Thus, the first question is "do the general public view congestion policies merely as traffic policies, as sustainability policies, or both?" We wanted to determine if the real reason for public opposition to congestion policies was the traffic features or the sustainable features.

Secondly, existing literature mainly focuses on the behavioral and policy-related factors for public acceptance of congestion charge policies, such as traffic inconvenience, trust in governmental agencies, and perceived fairness [15-19]. However, the moderating role of concern about smog and perceived smog risk has not been discussed. In other words, people with different levels of concern about smog and risk perception might have different prerequisites for behavioral and policy-related factors to accept congestion fees. Eliasson and Jonsson [20] revealed the strong causal relationship between citizens' smog concerns and their support of congestion charges and suggested that emphasizing the positive effects of congestion fees on air quality may have had a positive impact on acceptance. Considering the environmental features in a congestion charge policy, smog awareness, especially the smog concerns and perceived smog risk, may also have indirect impacts on policy acceptance via behavioral or policy-related factors. In other words, people with a higher level of concern about smog would not only recognize the sustainability goal embedded within the congestion charge policy and therefore support the policy, but would also be likely to sacrifice their transit inconvenience and support the congestion charge policy to some extent in exchange for a better environment. For example, some Beijing residents stated in an online poll that they would have supported a congestion fee if it would be effective at controlling smog, regardless of the infringement on traffic freedom [21]. Meanwhile, individuals who see congestion charge policies as a solution to environmental protection and sustainable development would raise concerns about the fairness of the policy process and their ability to participate in the policy-making process [22]. Therefore, the second question that this paper tries to explore is to what extent smog awareness, particularly smog concerns and perceived smog 
risks, indirectly influences the acceptance level of congestion charge policy as a moderator. Notably, this discussion is not only addressing Chinese smog control, but also environmental policy design theory as a whole. If individual awareness would indirectly influence perceived fairness and their chance of participation in the policy-making process, then, the policy maker should understand the mechanism of influence and how policy design should be changed accordingly.

Studying public acceptance of congestion charge policies is timely. A study conducted in Hangzhou revealed that $46.26 \%$ of respondents were willing to pay a congestion fee during peak hours, and the average amount people were willing to pay was 28.81 yuan per month [23]. However, less is known about the factors influencing public acceptance of congestion charges in China, especially the moderating role of smog awareness. This paper intends to fill this gap based on data collected from Beijing and Shanghai in August 2016, and answer the following research questions. We wanted to determine, in terms of smog control, how the public's smog awareness interacts with behavioral and policy-related factors to influence their acceptance of congestion charges. This paper is organized as follows: Section 2 presents a review of the literature, Section 3 introduces the design of the study and the data source, Section 4 provides results of empirical findings, and Section 5 presents conclusions and policy implications.

\section{Literature Review}

\subsection{Prior Studies on Public Acceptance of Congestion Charges}

This paper focuses on the concept of public acceptance, which represents citizen support of local implementation of sustainable projects or policies. Existing literature provided different definitions of 'acceptance'. Batel et al. [24] distinguished between the concepts of acceptance and support, stating that communities and individuals might accept energy technologies while not necessarily supporting them, and may not even know of their nearby existence. Wüstenhagen et al. [25] and Dermont et al. [26] clarified three dimensions of social acceptance, namely socio-political, community, and market acceptance. In this paper, what we investigated falls into the category of 'community acceptance', which refers to the specific acceptance of local stakeholders, particularly local residents, on certain projects. Considering we studied the acceptance of a proposed policy by local residents, rather than on an already approved project, the dependent variable is called "public preference toward congestion charge policy" following the work done by Dermont et al. [26]. However, all the smog control and traffic control studies we have cited use "public acceptance" as their chosen term. To reduce confusion, we used the term 'acceptance' with the clarification that this is not implementation acceptance but preference toward a proposal. Existing literature, although mainly based on data from Europe or the U.S., investigated key determinants of public acceptance of congestion charge policies [15-19]. Various factors have been tested through two perspectives, namely the individual behavioral perspective and the policy-related perspective [15-19,27-29].

Rooted in individual value judgment and behavioral studies, behavioral perspective argues that public acceptance of congestion fees is influenced by factors such as social norms, infringement on freedom, and socio demographic aspects [15,17-19]. Congestion charges contain a social dilemma wherein individuals' self-interests—such as driving comfortably—conflict with the collective interest, in this case, of abating the congestion problem [30]. A strong social norm of policy compliance would have a positive influence; people would be more likely to comply if they predict others are willing to comply [15]. When introducing congestion charges, individuals feel they are giving up freedom by paying for something has been free before, thus, their acceptance level will decrease because of infringement on their freedom $[15,16]$. Socio demographic factors, such as age, gender, car ownership, and driving frequency, also have significant impact on public acceptance of congestion charges [29].

Another dominating aspect focuses on how policy design and implementation would affect policy acceptance, with discussion about politically-related factors such as perceived effectiveness, perceived fairness, and trust in government $[15,16,27-29,31]$. Policy effectiveness and fairness are 
positively correlated with public acceptance toward a congestion charge. If the charge scheme is perceived as being effective for alleviating traffic congestion, the public will more likely support the scheme $[16,27,29]$. Similarly, the acceptance level will increase when individuals perceive that a congestion charge standard is fair and the majority can be benefit from this scheme $[15,18,28]$. From previous studies, trust in government is also considered as an important determinant of public acceptance [16,32]. Scholars have revealed that political trust has positive effects on both people's attitude toward government regulation and the level of compliance [33-35]. Especially for regressive economic policy tools, such as congestion charges, the effects of trust in government might be more important compared to perceived fairness or individual interests [36].

\subsection{New Influential Factors: Smog Concerns and Perceived Smog Risks}

Considering that the sustainability features in a congestion charge policy have been ignored in traffic policy discussions, this paper borrows public acceptance theories from studies focusing on sustainable development and environmental protection. In these policy areas, scholars stated that smog concerns and perceived risks of certain environmental problems were positively correlated with environmentally responsible behavior [29,37], and might enhance acceptance level of sustainability-oriented policies. It is worth noting that Chinese city governments emphasize smog control-related goals while designing congestion charge policy. For example, the "2013-2017 Beijing Clear Air Action Plan" clearly stated that one of the goals of the congestion fee charge policy is for smog control [38]. Thus, this paper considers smog awareness, including both smog concerns and perceived smog risks, as influential factors.

Firstly, following existing literature that defines environmental concerns as one's attitude toward facts, one's own behavior, or others' behavior, with consequences for environment [39-42], we define smog concerns as an individual's attitude toward smog crisis control, using willingness to pay (WTP) as measurement. Generally speaking, a positive relationship exists between environmental attitude and environmentally responsible behavior [29]. Especially in the context of a smog crisis, individuals who hold a pro-environmental attitude and show desire to control smog, are supposedly more willing to accept congestion charge policies. Secondly, risk perception originates from the study of public attitude toward nuclear power, wind energy, and climate change policies $[43,44]$, referring to an individual's subjective judgment of the adverse consequences of a particular hazard and threats to the environment or one's own health [45]. Particularly, we refer to perceived smog risks as the extent to which the general public feels uncertain risk caused by the smog crisis. For this aspect we used self-reported risk perception as the measurement. Numerous studies have shown that exposure to particulate matter $2.5 \mu \mathrm{m}$ or smaller $\left(\mathrm{PM}_{2.5}\right)$ can cause chronic respiratory and cardiovascular diseases, alter host defenses, and damage lung tissue [46,47]. Thus, if people perceive that the smog crisis will be harmful to their health or will worsen in the future, they tend to support a congestion charge to alleviate emissions, to thereby reduce smog.

Besides testing their direct impacts on smog policy acceptance, we emphasize their moderating impacts on public acceptance toward a congestion charge via behavioral and policy-related factors. In other words, people with different levels of smog concerns and perceived smog risks might have different prerequisites for behavioral and policy-related factors to accept a congestion fee. Fujii et al. [28] compared data in Japan, Taiwan, and Sweden and found that environmental concerns did not have a significant impact in any regression model, which denied a direct causal relationship. However, the correlation tests were positive and substantial in all three samples, which implied that environmental concerns could have an indirect effect on acceptance, mediated by some other independent variables, such as fairness. As for the moderating effect of perceived risk, this paper follows the findings of Moon and Balasubramanian [48] who suggested that risk perception served as a moderator on the influencing factors, such as political trust and other sociodemographic factors, in shaping public attitude toward agrobitoechnology, based on a large sample of survey data collected both in the United States and the United Kingdom. With similar levels of technological uncertainty 
and complexity of the policy solution, this paper regards perceived smog risk as having a similar moderating role in congestion charge acceptance.

Thus, interaction effects between smog awareness and other factors were tested to reveal how smog concerns and smog risk perceptions influence the effects of behavioral and policy-related factors on public acceptance of a congestion charge.

\section{Research Design and Data Source}

\subsection{Conceptual Model and Variable Specification}

Based on the above discussion, this research focuses on the role of smog awareness in public acceptance formation. Figure 1 illustrates the conceptual framework.

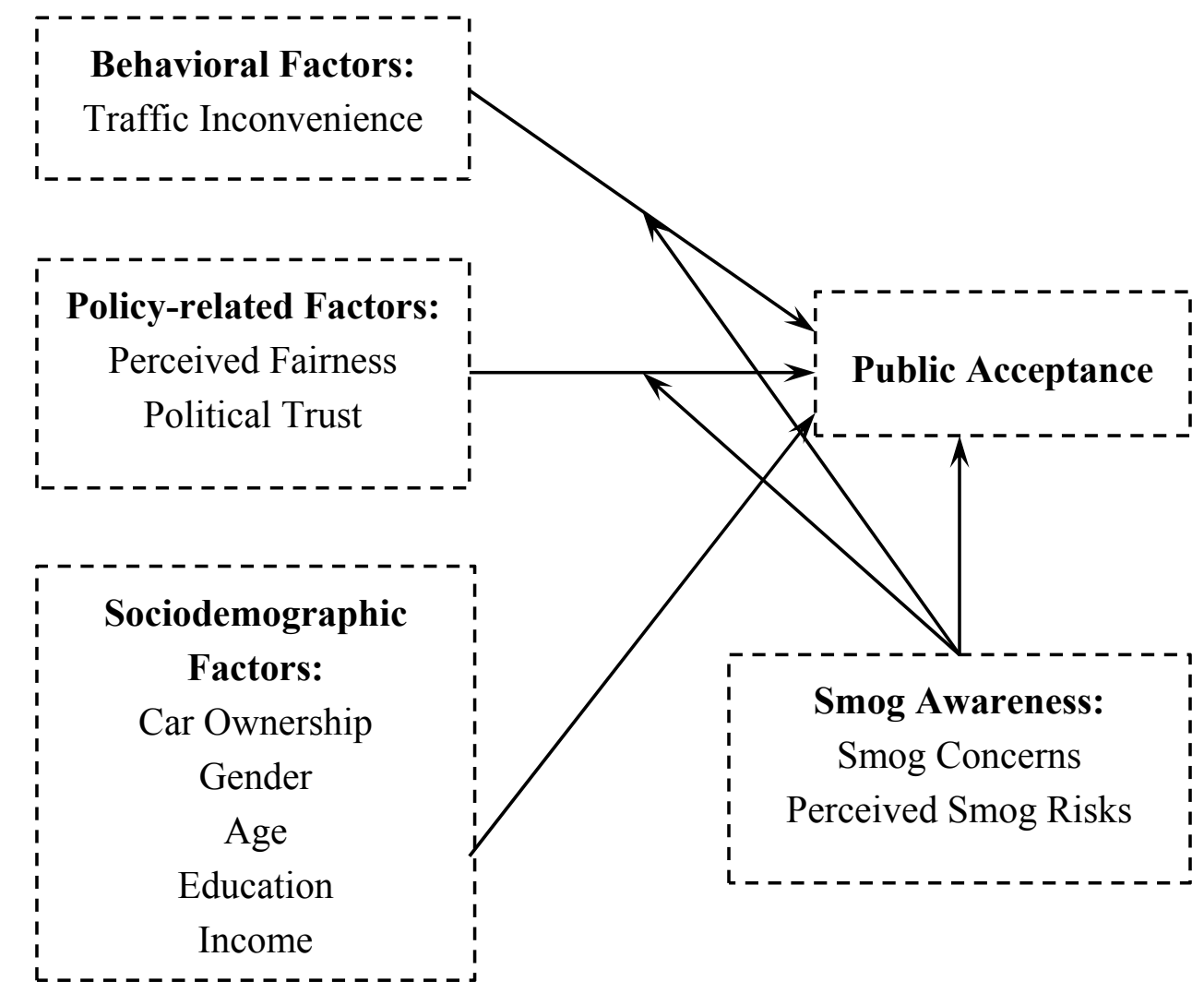

Figure 1. Conceptual framework: smog awareness and public acceptance toward congestion charges in China.

\subsubsection{Causalities between Smog Awareness and Public Acceptance}

As shown in Figure 1, previous studies mainly focused on the direct impact of behavioral, policy-related, and sociodemographic factors on public acceptance level, and neglected the moderating role of smog concerns and perceived smog risks. However, the influence of behavioral and policy-related elements on public acceptance might vary according to citizens' smog concerns and risk perceptions, that is, smog awareness might serve as moderator in the conceptual framework.

This study did not use an environmental perception measurement to address the "attitude-behavior gap", which describes the divergence between pro-environmental attitude and anti-environmental behavior, and this may lead to a construction validity problem [29]. Instead, we adopted a more direct behavioral measurement of smog concerns, such as willingness to pay, and asked the respondent, "How much money are you willing to pay for smog control per month?" The answer "unwilling to pay" was coded as 0, while "less than 50 yuan", "50-100 yuan", 
"100-200 yuan", “200-300 yuan", and "more than 300" were coded as 1 . The variable of 'willingness to pay' reflects people's behavioral smog concern, which reflects individual eagerness to control the smog crisis by sacrificing individual interests (i.e., pay for smog control). It is different from the concept of smog policy acceptance, which reflects citizens' judgment of government's effort of smog control and their willingness to comply. For instance, individuals who live or work in low emission areas might oppose a congestion charge policy even if they have high WTP. The real reason of opposition lies in the fact that they think it is an unfair policy.

The concept of perceived smog risk reflects an individual's judgment on the perceived hazards to health and the severity of the smog crisis, captured by responses to the statements of, "I think smog crisis is harmful to my health" and "I think the smog crisis in Beijing (Shanghai) will be more severe in the future", and the answers "strongly disagree", "disagree", and "neutral" were coded as 0 , while "agree", and "strongly agree" were coded as 1 . To better illustrate the role of risk perception, we obtained the average value of health risk and smog severity risk as the final value of risk perception.

\subsubsection{Causalities between Behavioral, Policy-Related, and Sociodemographic Factors and Public Acceptance}

Based on previous studies [10-14], we recognized that a series of exogenous factors may affect public acceptance, so we controlled them in the regression models. For the conceptual framework, we included three sets of exogenous variables drawn from the literature (Figure 1). The first set is the behavioral factor, measured by traffic inconvenience. Traffic inconvenience, reflecting infringement on people's freedom, was measured by the question, "Do you agree that congestion charge policies will bring traffic inconvenience to people's daily lives?"

The second set of variables is policy-related factors, including political trust and perceived fairness. In previous studies, political trust is usually captured by the question of: "How much do you trust the government generally?"; or "How much do you trust the institution of ... (specific name)?" However, political trust is dimension-specific. As Li [49] emphasized, the distinction between a politician's commitment to protect public interests and their competence to act are different types of political trust. Commitment to act refers to government agencies' promise keeping, caring about the public, incentive compatibility, or any combination of the three [50]. Competence to act refers to the capacity of political institutions to realize their commitments to protect public interests or achieve certain goals $[49,50]$. Besides commitment and capacity, political trust also involves other aspects, such as trust, in the policy-making process. Thus, this paper measured political trust with four statements, including trust in the policy-making process (i.e., "I think the process of smog control policy-making is open"), trust in competence (i.e., "I think local government has the ability to deal with the smog crisis in the short term." And "I think local government has implemented various policies for smog control."), and trust in commitment to act (i.e., "I think local government is willing to control smog."). This paper, then, created an index variable of political trust via factor analysis. The value of KMO is 0.7242 , which means it is very suitable to do factor analysis.

Perceived fairness, relating to the distribution of costs and benefits within society [51,52], can be captured from three principles, namely equality, equity, and need [53]. For congestion charge policies, equality implies that each car owner has the same obligation to pay for driving, whereas equity and need mean certain groups' obligations can be exempted or reduced. The standards of a congestion charge are consistent with equality principles around the world, not excepting the scheme under discussion in China. In this study, following the literature [54,55], perceived fairness is measured with the statement of equality principle, "I think each car owner has the obligation to pay the same congestion charge fee."

In addition to sociodemographic factors-including gender, age, income, and education-this paper also used car ownership as an important control variable, measured by, "How many cars do you have in your family?" Finally, the dependent variable is public acceptance, asking the respondents to judge the statement, "I support the government to enact a congestion charge policy to control 
smog pollution." Except for sociodemographic factors, all other measurements adopt the Likert-scale item $1-5$, where 1 is 'strongly disagree', 2 is 'disagree', 3 is 'neutral', 4 is 'agree', and 5 is 'strongly agree'.

For concepts with multiple measurements, we calculated Cronbach's $\alpha$ values to test if the average linear correlation among questions belongs to the same scale or not. Normally, the threshold is set at 0.7 to ensure the internal consistency [56]. However, it is worth noting that this standard is set to test consistency among a large number of measurement items, such as 14 or more [57]. Since a larger number of items can artificially inflate the alpha value, and we only have two and four items respectively, our measurements are quite reliable with Cronbach's $\alpha$ values all around 0.7 (Table 1).

Table 1. Reliability of questionnaire.

\begin{tabular}{ccc}
\hline Variable & Cronbach's $\alpha$ & Number of Items \\
\hline Political Trust & 0.7069 & 4 \\
Risk Perception & 0.6956 & 2 \\
\hline
\end{tabular}

\subsection{Data Source}

The survey was conducted in the summer of 2016 in Beijing and Shanghai, the two largest metropolises in China. Governments in both cities have started to discuss the feasibility of a congestion charge $[38,58]$. We noticed that the severity of the smog crisis in these two cities is different. According to the reports from Shanghai and Beijing Environmental Protection Agencies, there were 168 heavy smog-polluted days in Beijing, but only 14 heavy smog-polluted days in Shanghai, in 2016. The general difference between Beijing and Shanghai, including smog severity, is controlled by a dummy variable representing different cities in all models, with Shanghai being coded as 1 and Beijing as 0 . We realized that the city dummy could not determine if it was the smog or other differences that matter between Beijing and Shanghai. This is the measurement limitation with the two-city design.

We conducted an online survey with residents who have lived in either Beijing or Shanghai for at least 12 months by August 2016 and checked their acceptance level of a congestion charge. During the survey period, the average $\mathrm{PM}_{2.5}$ concentration ranged from $37-65 \mu \mathrm{g} / \mathrm{m}^{3}$ in Beijing and 10-51 $\mu \mathrm{g} / \mathrm{m}^{3}$ in Shanghai, both of which were categorized as "good air quality" according to the Air Quality Index standard of the National Environmental Protection Bureau [59]. Therefore, no significant weather influence existed to form a systematic bias of public acceptance.

We first provided the online survey link to students at Tsinghua University and developed our sample group following the "snow-ball" strategy [60]. In order to ensure qualified respondents pay sufficient attention to questions, we double-checked the time taken by each respondent on the questionnaire as a proxy of the data quality [61]. We dropped the sample if the respondent took far less time answering the survey than the average time. In the end, we had 574 valid questionnaires, 285 from Beijing and 289 from Shanghai. According to sample size calculation process [62], it would be acceptable if our sample size were more than 253 in Beijing and 139 in Shanghai. A detailed calculation process could be provided based on request.

As Table 2 shows, among the 574 respondents, $49.30 \%$ were male $(\mathrm{N}=283)$ and $50.70 \%(\mathrm{~N}=291)$ were female. The average age in our sample was 30 years old, which is younger than the city-level age average. People between 21 and 30 years old are over represented in this research. Also, 317 respondents $(55.23 \%)$ hold a college degree and $213(37.11 \%)$ hold a postgraduate degree or higher, which made the higher educated population over represented compared with the whole population distribution. Monthly income, measured in yuan (RMB), ranged from 7001 to 10,000 in our sample, which was higher than the average monthly income of 6906 yuan (RMB) in Beijing and 6378 yuan (RMB) in Shanghai. We attributed these selection biases to using an online survey method, which naturally over represents people who are younger, better educated, with higher monthly income. Nearly half of the respondents ( $N=276$ ) had no car in their family, 240 of them had one car, and only 58 respondents had two or more cars. 
Table 2. Sociodemographic summary $(\mathrm{N}=574)$.

\begin{tabular}{|c|c|c|c|c|c|c|c|}
\hline & Background & Frequency & $\begin{array}{c}\text { Percentage } \\
(\%)\end{array}$ & $\begin{array}{c}\text { Sample } \\
\text { from } \\
\text { Beijing } \\
(\%)\end{array}$ & $\begin{array}{c}\text { Sample } \\
\text { from } \\
\text { Shanghai } \\
(\%)\end{array}$ & $\begin{array}{c}\text { Distribution } \\
\text { of Beijing } \\
\text { Population } \\
(\%)\end{array}$ & $\begin{array}{c}\text { Distribution } \\
\text { of Shanghai } \\
\text { Population } \\
(\%)\end{array}$ \\
\hline \multirow[b]{2}{*}{ Gender } & Male & 283 & 49.30 & 56.49 & 42.21 & 50.18 & 51.50 \\
\hline & Female & 291 & 50.70 & 43.51 & 57.79 & 49.82 & 48.50 \\
\hline \multirow{5}{*}{ Age } & $<21$ & 18 & 3.14 & 3.51 & 2.77 & 3.90 & 4.87 \\
\hline & $21-30$ & 359 & 62.54 & 58.95 & 65.74 & 21.70 & 22.55 \\
\hline & $31-40$ & 149 & 25.96 & 28.42 & 23.53 & 18.50 & 17.59 \\
\hline & $41-50$ & 33 & 5.75 & 6.67 & 5.19 & 16.40 & 15.98 \\
\hline & $>50$ & 15 & 2.61 & 2.46 & 2.77 & 22.90 & 30.39 \\
\hline \multirow{6}{*}{ Income } & $<2000$ & 18 & 3.14 & 3.51 & 2.77 & 3.00 & 3.50 \\
\hline & $2000-4000$ & 33 & 5.75 & 8.07 & 3.46 & 23.30 & 28.20 \\
\hline & $4001-7000$ & 127 & 22.13 & 25.26 & 19.03 & 27.95 & 27.85 \\
\hline & $7001-10,000$ & 119 & 20.73 & 24.56 & 16.96 & 19.25 & 17.85 \\
\hline & $10,001-20,000$ & 172 & 29.97 & 27.37 & 32.53 & 18.70 & 16.90 \\
\hline & $>20,000$ & 105 & 18.29 & 11.23 & 25.26 & 7.30 & 5.70 \\
\hline \multirow{4}{*}{ Education } & Middle school or below & 10 & 1.74 & 3.51 & - & 39.22 & 55.34 \\
\hline & High school & 34 & 5.92 & 7.02 & 4.84 & 15.36 & 21.84 \\
\hline & College & 317 & 55.23 & 48.42 & 61.94 & 38.61 & 20.91 \\
\hline & Masters or above & 213 & 37.11 & 41.05 & 33.22 & 4.72 & 1.90 \\
\hline \multirow{3}{*}{ Car } & None & 276 & 48.08 & 50.53 & 46.02 & 74.72 & 86.01 \\
\hline & 1 & 240 & 41.81 & 40.00 & 43.60 & \multirow{2}{*}{25.28} & \multirow{2}{*}{13.99} \\
\hline & $>1$ & 58 & 10.10 & 9.47 & 10.38 & & \\
\hline
\end{tabular}

Data source: data collected by authors, and Beijing Census Data in 2014 [63], reports of Beijing average monthly income [64], Shanghai Census Data in 2014 [65], reports of Shanghai average monthly income [66], and car park in 2016 [67].

\section{Results}

\subsection{Descriptive Statistics}

Table 3 summarizes the descriptive statistics of all the variables. Most respondents supported a congestion charge to alleviate smog pollution, with $33.4 \%$ of participants agreeing with the scheme and $9.91 \%$ strongly agreeing with it. With regards to individual features, $65.16 \%$ of respondents were willing to pay to control smog pollution, while $85.37 \%$ thought that the smog crisis is harmful to their health, and $56.45 \%$ agree that the smog crisis might be aggravated in the future.

Table 3. Summary of the variables and descriptive statistics from the questionnaire.

\begin{tabular}{|c|c|c|c|c|c|}
\hline \multicolumn{3}{|c|}{ Variables } & \multirow{2}{*}{$\begin{array}{c}\text { Mean } \\
3.16\end{array}$} & \multirow{2}{*}{$\begin{array}{c}\text { Std. Dev. } \\
1.14\end{array}$} & \multirow{2}{*}{$\frac{\text { Scale }}{1-5}$} \\
\hline Dependent variables & Public ac & tance & & & \\
\hline \multirow{9}{*}{ Independent variables } & \multirow{4}{*}{ Political trust } & Willingness & 2.97 & 1.11 & $1-5$ \\
\hline & & Various & 2.76 & 1.01 & $1-5$ \\
\hline & & Capacity & 2.35 & 1.01 & $1-5$ \\
\hline & & Openness & 2.96 & 1.10 & $1-5$ \\
\hline & \multirow{3}{*}{\multicolumn{2}{|c|}{$\begin{array}{c}\text { Perceived fairness } \\
\text { Traffic inconvenience } \\
\text { WTP }\end{array}$}} & 2.84 & 1.20 & $1-5$ \\
\hline & & & 2.45 & 1.04 & $1-5$ \\
\hline & & & 0.65 & 0.48 & 0 or 1 \\
\hline & \multirow{2}{*}{ Risk perception } & Healthy & 0.85 & 0.35 & 0 or 1 \\
\hline & & Severity & 0.56 & 0.50 & 0 or 1 \\
\hline \multirow{5}{*}{ Control variables } & \multicolumn{2}{|c|}{ Car } & 0.64 & 0.71 & $0-3$ \\
\hline & \multirow{2}{*}{\multicolumn{2}{|c|}{$\begin{array}{l}\text { Age } \\
\text { Gender }\end{array}$}} & 30.45 & 7.71 & $14-69$ \\
\hline & & & 0.51 & 0.50 & 0 or 1 \\
\hline & \multicolumn{2}{|c|}{ Education } & 3.27 & 0.65 & $1-4$ \\
\hline & \multicolumn{2}{|c|}{ Income } & 4.27 & 1.37 & $1-7$ \\
\hline
\end{tabular}


Political trust was measured in four dimensions, that is, willingness to control smog, various measures to control smog, capacity to control smog, and openness of the policy-making process. Among them, political trust in the government's willingness to control smog was highest, with a mean of 2.97, while most people have low confidence in the government's capacity. For perceived fairness, $32.35 \%$ of participants oppose the standards of the congestion charge under discussion, and $23.13 \%$ hold a neutral attitude. In addition, few respondents think that smog control policies would bring traffic inconvenience to their daily life, with a mean of 2.43 .

\subsection{Regression Results}

To better delineate the causality of the individual features and public acceptance toward a congestion charge, we used an ordered logistic regression in the model, as most variables in our survey were either binary or coded ordinals by Likert-scale $1-5$. The ordered logistic model can be expressed as

$$
\mathrm{y}^{*}=\mathrm{X} \beta+u, u \mid \mathrm{X} \sim \log \text { it }(0,1)
$$

where $\mathrm{y}^{*}$ is the exact but unobserved latent variable, $\mathrm{X}$ is the vector of independent variables, $u$ is the error term, and $\beta$ is the vector of regression coefficients which we wished to estimate. Model 1 was the base model that only contained behavioral, policy-related, and sociodemographic factors; while Models 2 and 3 considered the influence of smog awareness in different ways.

To test the fitness of the ordered logistic model in our research, we first used the Brant test package developed by Benjamin Schlegel to verify the parallel regression assumption in $\mathrm{R}$ with version 3.3.3. The results of three models all stated "H0: parallel regression assumption holds", which justifies the application of the ordered logistic model in this study. Regression results of the three models are displayed in Table 4.

Table 4. Regression results of the determinants of congestion charge acceptance.

\begin{tabular}{|c|c|c|c|c|c|c|}
\hline & \multicolumn{2}{|c|}{ Model 1} & \multicolumn{2}{|c|}{ Model 2} & \multicolumn{2}{|c|}{ Model 3} \\
\hline & Coef. & $\mathbf{T}$ & Coef. & $\mathbf{T}$ & Coef. & $\mathbf{T}$ \\
\hline Traffic Inconvenience & $-0.20 * *$ & -2.51 & $-0.15^{* *}$ & -1.96 & $-0.17 * *$ & -2.08 \\
\hline Perceived Fairness & $0.54^{* * * *}$ & 7.47 & $0.49 * * * *$ & 6.77 & $0.48^{* * * *}$ & 6.57 \\
\hline Political Trust & $0.44^{* * * *}$ & 4.25 & $0.45^{* * * *}$ & 4.19 & $0.43^{* * * *}$ & 3.97 \\
\hline WTP & & & $1.47^{* * * *}$ & 6.23 & $1.62 * * * *$ & 6.56 \\
\hline Risk Perception & & & $0.52 * *$ & 2.17 & $0.53 * *$ & 2.18 \\
\hline WTP $\times$ Traffic Inconvenience & & & & & -0.04 & -0.20 \\
\hline WTP $\times$ Perceived Fairness & & & & & $0.32 *$ & 1.84 \\
\hline WTP $\times$ Political Trust & & & & & -0.25 & -1.08 \\
\hline Risk Perception $\times$ Traffic Inconvenience & & & & & 0.13 & 0.48 \\
\hline Risk Perception $\times$ Perceived Fairness & & & & & $0.62 * * *$ & 2.86 \\
\hline Risk Perception $\times$ Political Trust & & & & & 0.01 & 0.02 \\
\hline Car & $-0.51 * * * *$ & -4.07 & $-0.53^{* * * *}$ & -4.24 & $-0.51^{* * * *}$ & -4.03 \\
\hline \multicolumn{7}{|l|}{ Age Group } \\
\hline $21-55$ & -0.05 & -0.07 & 0.09 & 0.12 & 0.04 & 0.06 \\
\hline $56-69$ & -0.54 & -0.58 & -0.20 & -0.21 & -0.30 & -0.31 \\
\hline Gender & -0.09 & -0.56 & -0.13 & -0.86 & -0.14 & -0.89 \\
\hline \multicolumn{7}{|l|}{ Education } \\
\hline 2 & $-1.30 *$ & -1.92 & -1.00 & -1.48 & -0.86 & -1.26 \\
\hline 3 & $-1.52 * *$ & -2.40 & $-1.44^{* *}$ & -2.29 & $-1.34 * *$ & -2.12 \\
\hline 4 & $-1.24 *$ & -1.91 & -1.18 * & -1.84 & $-1.12 *$ & -1.72 \\
\hline Income & $0.12 *$ & 1.74 & 0.12 * & 1.83 & 0.12 * & 1.70 \\
\hline Area & 0.10 & 0.61 & $-0.47^{* *}$ & -2.54 & $-0.51^{* * *}$ & -2.73 \\
\hline$R^{2}$ & \multicolumn{2}{|c|}{0.0731} & \multicolumn{2}{|c|}{0.0987} & \multicolumn{2}{|c|}{0.1058} \\
\hline$N$ & \multicolumn{2}{|c|}{574} & \multicolumn{2}{|c|}{574} & \multicolumn{2}{|c|}{574} \\
\hline
\end{tabular}

Notes: ${ }^{* * * *}$ denotes significant at 0.001 level; ${ }^{* * *}$ denotes significant at 0.01 level; ${ }^{* *}$ denotes significant at 0.01 level; and ${ }^{*}$ denotes significant at 0.10 level. 


\subsubsection{Direct Positive Correlation between Smog Awareness and Public Acceptance}

Models two and three show that smog awareness influences policy acceptance. Firstly, people who are more willing to pay for smog control tend to be more supportive of a congestion charge policy (model two: $\beta=1.47, p$-value $<0.001$, model three: $\beta=1.62, p$-value $<0.001$ ) (Table 4 ). This result verifies our hypothesis that individuals with a higher level of WTP place higher value on environment quality so that they are more likely to sacrifice material value in exchange for smog control, and tend to be more supportive of a congestion charge.

Secondly, perceived risk of health hazards and smog severity had a significantly positive correlation with public acceptance (model two: $\beta=0.52, p$-value $<0.05$, model three: $\beta=0.53$, $p$-value $<0.05$ ) (Table 4). This result demonstrates that risk perceptions improve citizens' acceptance of a congestion charge: the more people think smog would result in negative health impacts or that smog will worsen in the future, the more they are likely to act against it by supporting policy solutions, such as a congestion fees.

Both results illustrate that smog awareness has a direct and positive relationship with public acceptance, which conforms with previous studies [68]. This implies that individuals with various levels of smog concern and risk perception would react differently to a congestion charge policy: those with stronger concerns about smog and a greater risk perception would be more willing to accept a congestion charge policy, and those with lower levels of smog and risk perception would be less likely to accept the policy. The purpose of this paper is not to discuss how to increase a person's WTP for smog reduction, as many studies have mentioned key elements to increase WTP, including individual knowledge of smog sources, protection methods, and the provision and accessibility of smog information $[69,70]$. Therefore, if policy makers could help raise the risk awareness or WTP of the general public through different policy instruments, it is highly likely that they would directly increase the public acceptance level of smog control policies.

\subsubsection{Moderating Influence of Smog Awareness on Perceived Fairness}

As model three shows, the interaction of WTP and perceived fairness is positive with public acceptance $(\beta=0.32, p$-value $<0.10)$, and the interaction of risk perception and perceived fairness also has a significantly positive relationship with public acceptance $(\beta=0.62, p$-value $<0.01)$. These interaction results show that people with higher smog concerns or risk perceptions of the smog crisis have higher elasticity in the fairness of a congestion charge policy. This clearly illustrates the moderating influence of WTP and risk perception that can strengthen the positive relationship between perceived fairness and acceptance level. Thus, the public's judgment of fairness is important, especially to those with higher WTP or risk perception.

Sustainable solutions challenge policy design by pursuing collective benefits [71,72]. Regarding a congestion charge, there exists a social dilemma where individual interests, such as enjoying the comfort and convenience of driving, will be sacrificed in pursuit of the collective good, in this case reducing traffic to reduce smog pollution [30]. Thus, perceived fairness, which refers to the distribution of benefits and burdens within various groups of citizens, matters more in regard to the public's acceptance of sustainable policies. Equality and fairness are essential elements in sustainable development, and thus play a large role in congestion charge policy design and public acceptance. Both the design of the traffic control area and the design of a charge rate can have significant fairness impacts through the distribution of costs and benefits. This research found that people with a higher level of smog concern or risk perception are more aware of and sensitive to this equality issue.

We propose two possible explanations for further empirical studies. Firstly, as many studies have found, environmental concerns have a close relationship with fairness concerns [73]. Individuals who value sustainable or environmental protection goals may also have higher levels of concern for fairness. Awareness of environmental risks is usually associated with left-wing orientation, which values a liberal political environment [68]. Yet, the detailed influencing mechanism for smog concerns and risk perceptions toward equality concerns still requires further empirical investigation. Secondly, 
individuals with higher smog concerns or risk perceptions have a greater willingness to alleviate smog pollution via various policies. Besides their own acceptance of a congestion charge verified by the direct effect of risk perception, they also want more people to accept this policy, ensuring the successful implementation and effectiveness of smog control. As distributional fairness is essential to public acceptance, those with higher concerns about smog or risk perceptions place a higher emphasis on this factor, allowing a policy to gain public support and be successfully implemented.

\subsubsection{Positive Relationship between Policy-Related Factors and Public Acceptance}

As the results show, perceived fairness positively influenced public acceptance of a congestion charge (model one: $\beta=0.54, p$-value $<0.001$, model two: $\beta=0.49, p$-value $<0.001$, and model three: $\beta=0.48, p$-value $<0.001$ ) (Table 4 ). If people agree with the distributional standard of the congestion charge, they tend to be more willing to accept the policy. Meanwhile, those who have a greater trust in governmental agencies are more likely to support a congestion charge (model one: $\beta=0.44, p$-value $<0.001$, model two: $\beta=0.45, p$-value $<0.001$, model three: $\beta=0.43$, $p$-value $<0.001$ ) (Table 4). These significant positive influences of the policy-related factors are consistent with previous studies [35,55]. Citizens are more likely to abide by the decisions of political agencies if they perceive these agencies as legitimate, whereas citizens with low political trust intend to calculate the costs and benefits of compliance and be non-compliant [74]. Additionally, as a congestion charge has an embedded social dilemma where individual interests will be sacrificed in pursuit of collective goods [30], distributional fairness is especially crucial to public acceptance [15,55].

\subsubsection{Behavioral Factors and Car Ownership Negatively Influence Public Acceptance}

Behavioral factors, namely traffic inconvenience, had a significant negative effect on public acceptance of a congestion charge in the three models (model one: $\beta=-0.20, p$-value $<0.05$, model two: $\beta=-0.15, p$-value $<0.05$, and model three: $\beta=-0.17, p$-value $<0.05$ ) (Table 4 ). As a congestion charge might be viewed as an infringement on travelling freedom, those who place a high value on traffic convenience would be less likely to accept this policy [15]. Similarly, car owners tend to oppose the idea of a congestion charge, as they are the target audience of this policy in all models (model one: $\beta=-0.51, p$-value $<0.001$, model two: $\beta=-0.53$, $p$-value $<0.001$, model three: $\beta=-0.51$, $p$-value $<0.001$ ) (Table 4 ).

For sociodemographic variables, respondents with higher education tend to oppose congestion charges as they might suspect the legitimacy of this policy (Table 4). In addition, income has positive effects on a congestion fee when considering the smog crisis, as richer people might care more about environmental protection rather than paying for driving their car (Table 4). Moreover, people living in Shanghai have a lower acceptance level than those living in Beijing (model two: $\beta=-0.47$, $p$-value $<0.05$; model 3: $\beta=-0.51, p$-value $<0.01$ ) (Table 4), which might be because the smog pollution is less severe in Shanghai.

\section{Conclusions and Policy Implications}

In many Chinese cities, smog pollution has become a severe environmental disaster that not only threatens public health, but has also created a significant challenge for the country to fulfill its sustainable development goals. The Beijing and Shanghai city governments plan to adopt congestion charge policies to reduce traffic jams and control smog pollution, following western countries such as the United Kingdom. However, public debates and public opposition have postponed the policy-making and implementation process. Two key aspects for the Chinese government to explore include the key determinants of public opposition and how these determinants impact public acceptance.

This paper contributes to the growing body of literature on public acceptance of a congestion charge while considering the moderating effect of smog awareness, including smog concern and perceived smog risks. We tested both the direct role and the moderating role of smog awareness on 
public acceptance. Using data derived from Beijing and Shanghai in August 2016, we used ordered logistic regression to examine the influence of WTP and risk perceptions. The research findings suggest that both WTP and risk perception are positively correlated with public acceptance, and those with greater concerns about smog or risk perceptions place a higher emphasis on perceived fairness.

Policy implications of this paper are two-fold. Echoing existing literatures, perceived fairness as well as political trust have a significant positive relationship with public acceptance. Therefore, participatory policymaking that involves the public in the decision-making process can enhance people's trust in government agencies, and increase the legitimacy of the distribution standards in a congestion charge design. Practitioners should consider designing various mechanisms to engage citizens, thereby achieving key democratic values such as legitimacy, justice, and effectiveness in governance $[75,76]$. Meanwhile, traffic inconvenience presents a significant negative impact on the acceptance of a congestion charge, and this impact is not negated by personal environmental preference. This implies that the majority of citizens still see a congestion charge as a traffic policy rather than as a sustainable policy. Therefore, governments should provide the public with clean, efficient, and convenient transportation alternatives to gain public support. Public education, however, may be provided via other channels. As results show, citizens who have higher levels of smog concerns and risk perceptions are more likely to directly support a congestion charge policy. Therefore, the government should organize publicity and public discussions on smog in an open manner. Environmental education, scientific knowledge publicity about smog, or illustrations of the effectiveness of smog control policies might all make the public more aware of the issue and supportive of the congestion charge as a result.

Secondly, as smog awareness plays an important role in public acceptance of a congestion charge, practitioners should pay more attention to people's smog awareness in order to improve public support and gain legitimacy. With regard to policies that contain environmental or sustainable goals, individual concerns about a smog crisis and potential risks may especially influence the effort of other factors, such as policy fairness. In this sense, policy makers should place a higher emphasis on policy fairness presented in environmentally-oriented policies compared with other policies. This could explain why China has encountered major public opposition on issues related to the environment, and the public mainly argued for policy transparency, openness, and fairness.

Although this paper introduces further study topics with regard to public acceptance of sustainable policies, limitations still exist. Our sample size included only 574 respondents from two large cities, Beijing and Shanghai, which might threaten the applicability and validity of the paper in other locations. Extended sampling is needed in future research to better represent the general public with regards to a congestion charge policy. Also, this paper follows many existing studies on perception and testing respondents' subjective attitudes, willingness, or opinions, but not their actual behaviors. We noticed that there has been no consensus on how self-reported perception actually measures individual behaviors, especially within sustainable or environmental contexts [77]. We also noticed that measuring actual citizen opposition toward a congestion charge policy would be difficult. Potentially, a case study could be built to extend academic observation to how citizens present their opposing behavior toward this policy in the future. Nevertheless, this research sheds light on some of the mechanisms of public acceptance formation and takes smog awareness into consideration, providing practical implications for policy makers when implementing congestion charge policies in the future.

Acknowledgments: The authors would like to thank Feng Xu, Yanxiang Feng and Yangyang Xie for their great help in data collection process. Work reported in this paper was in part supported by the National Science Foundation (Project No. 71520107005), and by Volvo Group in a research project of the Research Center for Green Economy and Sustainable Development, Tsinghua University (Project No. 20153000181).

Author Contributions: Zhou, L. initiated the research question; Zhou, L. and Dai, Y. jointly designed survey questionnaire, analyzed the data, and wrote the paper.

Conflicts of Interest: The authors declare no conflict of interest. 


\section{References}

1. Xie, Y.; Zhao, B.; Zhang, L.; Luo, R. Spatiotemporal variations of $\mathrm{PM}_{2.5}$ and $\mathrm{PM}_{10}$ concentrations between 31 Chinese cities and their relationships with $\mathrm{SO}_{2}, \mathrm{NO}_{2}, \mathrm{CO}$ and $\mathrm{O}_{3}$. Particuology 2015, 20, 141-149. [CrossRef]

2. Cheng, S.; Lang, J.; Zhou, Y.; Han, L.; Wang, G.; Chen, D. A new monitoring-simulation-source apportionment approach for investigation the vehicular emission contribution to the $\mathrm{PM}_{2.5}$ pollution in Beijing, China. Atmos. Environ. 2013, 79, 308-316. [CrossRef]

3. Municipal Environmental Protection Bureau: 70\% of $\mathrm{PM}_{2.5}$ Pollution in Shanghai Comes from the Local. Available online: http:/ / www.shanghai.gov.cn/nw2/nw2314/nw2315/nw17239/nw17252/u21aw968232. html (accessed on 8 January 2015).

4. $60 \%$ of $\mathrm{PM}_{2.5}$ Pollution in Guangzhou Comes from the Industry, Vehicle and Dust. Available online: http:/ /www.gzepb.gov.cn/yhxw/201502/t20150205_78984.htm (accessed on 4 February 2017).

5. The Government in Hangzhou Launched the $\mathrm{PM}_{2.5}$ Source Apportionment Results: Vehicle Emission Topped. Available online: http:/ /zjnews.zjol.com.cn/system/2015/06/06/020686281.shtml (accessed on 6 June 2015).

6. The $\mathrm{PM}_{2.5}$ Source Apportionment Results of Nanjing Announced that Coal is the Largest pollution Source. Available online: http:/ /jsnews.jschina.com.cn/system/2015/04/30/024548067.shtml (accessed on 30 April 2015).

7. Zheng, Z.; Liu, Z.; Liu, C.; Shiwakoti, N. Understanding public response to a congestion charge: A random-effects ordered logit approach. Transp. Res. Part A 2014, 70, 117-134. [CrossRef]

8. Hensher, D.A.; Li, Z. Referendum voting in road pricing reform: A review of the evidence. Transp. Policy 2013, 25, 186-197. [CrossRef]

9. Finance Tencent. Why Did 61\% of the Public Oppose to the Congestion Fee? Is 20 Yuan too Expensive? Available online: http:/ / finance.qq.com/a/20160603/012060.htm (accessed on 18 August 2017).

10. Lieberthal, K.; Oksenberg, M. Policy Making in China: Leaders, Structures and Processes; Princeton University Press: Princeton NJ, USA, 1988.

11. Li, L. Rights consciousness and rules consciousness in contemporary China. China J. 2010, 64, 47-68. [CrossRef]

12. Wang, B. New media and communication mechanism of grass roots society-The case study of Jiangmen anti-nuclear movements. Jinan J. Philos. Soc. Sci. 2014, 11, 130-139.

13. Zhou, B. Media contact, public participation and political efficacy in public emergencies-The case study of the Xiamen PX project. Open Times 2011, 5, 123-140.

14. Wang, L.; Xu, J.; Qin, P. Will a driving restriction policy reduce car trips?-The case study of Beijing, China. Transp. Res. Part A 2014, 67, 279-290. [CrossRef]

15. Jakobsson, C.; Fujii, S.; Gärling, T. Determinants of private car users' acceptability of road pricing. Transp. Policy 2000, 7, 133-158. [CrossRef]

16. Kim, J.; Schmöcker, J.; Fujii, S.; Noland, R.B. Attitudes toward road pricing and environmental taxation among US and UK students. Transp. Res. Part A 2013, 48, 50-62. [CrossRef]

17. Schade, J.; Schlag, B. Public acceptability of traffic demand management in Europe. Traffic Eng. Control 2000, 41, 314-318.

18. Steg, L. Factors influencing the acceptability and effectiveness of transport pricing. In Acceptability of Transport Pricing Strategies; Schade, J., Schlag, B., Eds.; Elsevier: Oxford, UK, 2003.

19. Gärling, T.; Jakobsson, C.; Loukopoulos, P.; Fujii, S. Acceptability of road pricing. In Pricing in Road Transport: Multidisciplinary Perspectives; Verhoef, E., Bliemer, E., Steg, L., Van Wee, B., Eds.; Edward Elgar: Cheltenham, UK, 2008.

20. Eliasson, J.; Jonsson, L. The unexpected "yes": Explanatory factors behind the positive attitudes to congestion charges in Stockholm. Transp. Policy 2011, 18, 636-647. [CrossRef]

21. Smog Forced the Introduction of Congestion Charge. Available online: http://bj.people.com.cn/n/2015/ 1214/c82839-27314117.html (accessed on 14 December 2015).

22. Li, J.; Hiltunen, E.; He, X.; Zhu, L. A questionnaire case study to investigate public awareness of smog pollution in China's rural areas. Sustainability 2016, 8, 1111.

23. Shao, D.; Liu, X. Application of contingent valuation method on evaluating urban management policy: A contingent valuation on potential congestion charge during the peak hour in Hangzhou city. Urban Dev. Stud. 2015, 22, 118-124.

24. Batel, S.; Devine-Wright, P.; Tangeland, T. Social acceptance of low carbon energy and associated infrastructures: A critical discussion. Energy Policy 2013, 58, 1-5. [CrossRef] 
25. Wüstenhagen, R.; Wolsink, M.; Bürer, M.J. Social acceptance of renewable energy innovation: An introduction to the concept. Energy Policy 2007, 35, 2683-2691. [CrossRef]

26. Dermont, C.; Ingold, K.; Kammermann, L.; Stadelmann-Steffen, I. Bringing the policy making perspective in: A political science approach to social acceptance. Energy Policy 2017, 108, 359-368. [CrossRef]

27. Taylor, B.D.; Iseki, H.; Kalauskas, R. Addressing equity issues in political debated over road pricing. In Proceedings of the 89th Annual Meeting of the Transportation Research Board, Washington, DC, USA, 10-14 January 2010.

28. Fujii, S.; Gärling, T.; Jakobsson, C.; Jou, R.C. A cross-country study of fairness and infringement on freedom as determinants of car owners' acceptance of road pricing. Transportation 2004, 31, 285-295. [CrossRef]

29. Fransson, N.; Gärling, T. Environmental concern: Conceptual definitions, measurement methods, and research findings. J. Environ. Psychol. 1999, 19, 369-382. [CrossRef]

30. Dawes, R.M. Social dilemmas. Ann. Rev. Psychol. 1980, 31, 169-193. [CrossRef]

31. Bartley, B. Mobility impacts, reactions and opinions: Traffic demand management options in Europe: The MIRO project. Traffic Eng. Control 1995, 36, 596-603.

32. Schmöcker, J.-D.; Pettersson, P.; Fujii, S. Comparative analysis of proximal and distal determinants for the acceptance of coercive charging policies in the U.K. and Japan. Int. J. Sustain. Transp. 2012, 6, 156-173. [CrossRef]

33. Harring, N.; Jargers, S.C. Should we trust in values? Explaining public support for pro-environmental taxes. Sustainability 2013, 5, 210-227. [CrossRef]

34. Hammar, H.; Jagers, $\mathrm{S}$. What is a fair $\mathrm{CO}_{2}$ tax increase? Individual preferences for fair procedures for emission reductions in the transport sector. Ecol. Econ. 2007, 61, 377-387. [CrossRef]

35. Jagers, S.C.; Hammar, H. Environmental taxation for good and for bad: On individuals' reluctance to mitigate climate change via $\mathrm{CO}_{2}$-tax vis-à-vis alternative policy instruments. Environ. Politics 2009, 18, 218-237. [CrossRef]

36. Tyler, T.; Huo, Y.J. Trust in the Law; Russell Sage Foundation: New York, NY, USA, 2002.

37. Liobikienè, G.; Juknys, R. The role of values, environmental risk perception, awareness of consequences, and willingness to assume responsibility for environmentally-friendly behaviour: The Lithuanian case. J. Clean. Prod. 2016, 112, 3413-3422. [CrossRef]

38. The 2013-2017 Beijing Clear Air Action Plan. Available online: http://zhengwu.beijing.gov.cn/ghxx/qtgh/ t1324558.htm (accessed on 8 August 2017).

39. Weigel, R.H. Environmental attitudes and the prediction of behavior. In Environmental Psychology: Directions and Perspectives; Feimer, N.R., Geller, E.S., Eds.; Preager: New York, NY, USA, 1983; pp. 257-287.

40. Ajzen, I. Attitude structure and behaviour. In Attitude Structure and Function; Pratkanis, A.R., Breckler, S.J., Greenwald, A.G., Eds.; Erlbaum: Hillsdale, NJ, USA, 1989; pp. 241-274.

41. Sjöberg, L. Global change and human action: Psychological perspectives. Int. Soc. Sci. J. 1989, 121, 414-432.

42. Takala, M. Environmental awareness and human activity. Int. J. Psychol. 1991, 26, 585-597. [CrossRef]

43. Warren, C.R.; Lumsden, C.; O’Dowd, S.; Birnie, R.V. ‘Green on green': Public perceptions of wind power in Scotland and Ireland. J. Environ. Plan. Manag. 2005, 48, 853-875. [CrossRef]

44. Goodfellow, M.J.; Williams, H.R.; Azapagic, A. Nuclear renaissance, public perception and design criteria: An exploratory review. Energy Policy 2011, 39, 6199-6210. [CrossRef]

45. Aven, T.; Renn, O. Risk Management and Governance: Concepts, Guildelines and Applications; Springer: Dordrecht, The Netherlands, 2010.

46. Chen, Y.; Ebenstein, A.; Greenstone, M.; Li, H. Evidence on the impact of sustained exposure to air pollution on life expectancy from China's Huai River policy. Proc. Natl. Acad. Sci. USA 2013, 110, 12936-12941. [CrossRef] [PubMed]

47. Zhang, D.; Liu, J.; Li, B. Tackling air pollution in China-What do we learn from the great smog of 1950s in London. Sustainability 2014, 6, 5322-5338. [CrossRef]

48. Moon, W.; Balasubramanian, S.K. Public attitudes toward agrobiotechnology: The mediating role of risk perceptions on the impact of trust, awareness, and outrage. Rev. Agric. Econ. 2004, 26, 186-208. [CrossRef]

49. Li, L. Political trust and petitioning in Chinese countryside. Comp. Politics 2012, 40, 209-226. [CrossRef]

50. Levi, M.; Stoker, L. Political trust and trustworthiness. Ann. Rev. Political Sci. 2000, 3, 475-507. [CrossRef]

51. Eriksson, L.; Garvill, J.; Nordlund, A.M. Acceptability of single and combined transport policy measures: The importance of environmental and policy specific beliefs. Transp. Res. Part A 2008, 42, 1117-1128. [CrossRef] 
52. Schuitema, G.; Steg, L.; Forward, S. Explaining differences in acceptability before and acceptance after the implementation of a congestion charge in Stockholm. Transp. Res. Part A 2010, 44, 99-109. [CrossRef]

53. Deutsch, M. Equity, equality, and need: What determines which value will be used as the basis of distributive justice. J. Soc. Issues 1975, 31, 137-149. [CrossRef]

54. Jagers, S.; Löfgren, Å.; Stripple, J. Attitudes to personal carbon allowances: Political trust, fairness and ideology. Clim. Policy 2010, 10, 410-431. [CrossRef]

55. Zannakis, M.; Wallin, A.; Johansson, L.-O. Political trust and perceptions of the quality of institutional arrangements-How do they influence the public's acceptance of environmental rules. Environ. Policy Gov. 2015, 25, 424-438. [CrossRef]

56. Nunnally, J.C. Psychometric Theory; Tata McGraw-Hill Education: New York, NY, USA, 2010.

57. Cortina, J.M. What is coefficient alpha? An examination of theory and applications. J. Appl. Psychol. 1993, 78, 98-104. [CrossRef]

58. End the Plate Auction in Shanghai, and Change to Congestion Charge Policy after 7 Years? Available online: http:/ / business.sohu.com/20150203/n408382391.shtml (accessed on 3 February 2015).

59. Data Center of National Environmental Protection Bureau. Available online: http:/ / datacenter.mep.gov.cn (accessed on 14 August 2017).

60. Noy, C. Sampling knowledge: The hermeneutics of snowball sampling in qualitative research. Int. J. Soc. Res. Methodol. 2008, 11, 327-344. [CrossRef]

61. Huang, H. International knowledge and domestic evaluations in a changing society: The case of China. Am. Political Sci. Rev. 2015, 109, 613-634. [CrossRef]

62. Levin, J.; Fox, J.-M.; Forde, D.-R. Elementary Statistics in Social Research; Pearson Education, Inc.: New York, NY, USA, 2016.

63. How Much You Know about the Population in Beijing? Available online: http://www.bjstats.gov.cn/rkjd/ (accessed on 14 August 2017).

64. The Average Income of Beijing Citizens in 2016. Available online: http:/ / www.cngold.com.cn/newtopic/ 20160727/2016nbjpjgzsds.html (accessed on 19 August 2016).

65. 2014 Shanghai Statistical Yearbook. Available online: http://www.stats-sh.gov.cn/tjnj/tjnj2014.htm (accessed on 10 August 2016).

66. The Average Income of Shanghai Citizens in 2016. Available online: http://shebao.yjbys.com/zhengce/ 561397.html (accessed on 7 March 2017).

67. The Ranking of Car Park in 2016. Available online: http://www.sohu.com/a/124633891_565969 (accessed on 18 January 2017).

68. Drews, S.; Van den Bergh, J.C. What explains public support for climate policies? A review of empirical and experimental studies. Clim. Policy 2016, 16, 855-876. [CrossRef]

69. Sun, C.; Yuan, X.; Xu, M. The public perceptions and willingness to pay: From the perspective of the smog crisis in China. J. Clean. Prod. 2016, 112, 1635-1644. [CrossRef]

70. Wang, Y.; Sun, M.; Yang, X.; Yuan, X. Public awareness and willingness to pay for tackling smog pollution in China: A case study. J. Clean. Prod. 2016, 112, 1627-1634. [CrossRef]

71. Hardin, G. The tragedy of the commons. Science 1968, 162, 1243-1248. [CrossRef] [PubMed]

72. Ostrom, E. Governing the Commons: The Evolution of Institutions for Collective Action; Cambridge University Press: Cambridge, UK, 1990.

73. Toth, F.L. Fair Weather: Equity Concerns in Climate Change; Routledge: Abingdon, UK, 2013; Volume 6.

74. Tyler, T. Why People Obey the Law, 2nd ed.; Princeton University Press: Princeton, NJ, USA, 2006.

75. Fung, A. Varieties of participation in complex governance. Public Adm. Rev. 2006, 66, 66-75. [CrossRef]

76. Fung, A. Putting the public back into governance: The challenges of citizen participation and its future. Public Adm. Rev. 2015, 75, 513-522. [CrossRef]

77. Kormos, C.; Gifford, R. The validity of self-report measures of proenvironmental behavior: A meta-analytic review. J. Environ. Psychol. 2014, 40, 359-371. [CrossRef]

(C) 2017 by the authors. Licensee MDPI, Basel, Switzerland. This article is an open access article distributed under the terms and conditions of the Creative Commons Attribution (CC BY) license (http:// creativecommons.org/licenses/by/4.0/). 